Vol 4 No 1, 2021

pp. 1-11

\title{
Implementation of Experience Design on Museum Interiors. Case Study: East Java Cultural Museum
}

\author{
Allicia Sandra Meirissa, Titihan Sarihati, Vika Haristianti \\ Department of Interior Design, School of Creative Industries, Telkom University, Bandung, Indonesia
}

Corresponding e-mail: alliciatjan@gmail.com

Article info:

Received: 6-8-2021, Revised: 26-10-2021, Accepted: 27-10-2021

\begin{abstract}
This study examines the involvement of interior design with the purpose of museums in aspects of education, recreation, and conservation. This research aims to provide effective solutions in the design of museum interiors to meet the museum's purpose and become the basis for future research. The research creates designs that support spatial experiences, with a focus on cultural museums. The method used in this study is a qualitative method with three stages of triangulation (interviews, observations, and documents). The case study in this study is the East Java Cultural Museum. This research shows that spatial experience influences the achievement of the purpose of museums in cultural museums. There are five elements supporting the creation of a visitor's spatial experience in the museum, including room atmosphere, lighting, museum display case, storyline, and interactive aspects. These five aspects are united in an "Experience Design".
\end{abstract}

Keywords: Interior Design, Museum, Spatial Experience, Experience Design

\section{Introduction}

Indonesia is a country with much cultural diversity that has existed for a long time. One proof is that there are many historical and cultural relics from the royal era to the present day. However, because of the rapid flow of globalization, culture at the national level began to erode (Nahak, 2019). One of the government's efforts to maintain it is by preserving cultural heritage through the existence of museums. Based on the Kemendikbud.go.id page, in 2019, Indonesia has 439 museums spread across the country.

The museum itself has opportunities for Indonesia's tourism potential, for example, tourism potential in East Java. Based on data from the East Java Provincial Cultural and Tourism Office, the number of tourist visits in 2017 increased by $13.01 \%$, and tourists increased by $11.62 \%$. Cultural and historical visits are ranked fourth in destinations frequented by people. East Java culture has not been well accommodated. East Java has 64 museums (Mufidah, 2019), but none have a complete cultural collection.

The museum's establishment cannot be separated from its purpose as a medium of education, conservation, and recreation for the community (Mufidah, 2019). One aspect that can support the achievement of the museum's purpose is to pay attention to the museum's interior design. Interior design has an essential role in increasing the appeal of museums in the community (Lelo \& Laksono, 2018). The interior of the museum should be of interest to the public. Museums should be supported by designs that provide a spatial experience so that visitors have memorable things, a desire to return, to recommend them to others (Elgammal et al., 2020).

The spatial experience itself is related to the human senses, one of which is the sense of sight that correlates with interior design. Regarding visuals, aspects of colour, shape or 
ornamentation, and lighting can affect visitors' spatial experience (Gunawan et al., 2020). The formation of lighting impacts the atmosphere of the museum space, which affects the interaction and behaviour of visitors (Banaim \& Sarihati, 2019). Lighting is related to colour and colour associated with space (Sari, 2005). The form element gives rise to human perception, which ultimately supports creating a sense of space (Sari, 2005). In addition to the things that have been mentioned, the spatial experience can arise by inviting visitors to play an active role in the museum, such as with interactive screens (Suyono, Sarihati, \& Wulandari, 2019). The technology itself offers an opportunity for visitors to be motivated to explore the museum (Falk, 2016).

Knowing and applying elements in interior design to support the achievement of the museum's purpose is the focus of this research. The absence of research on the interior design spatial experience of cultural museums is also one of the emergences of this research. The scope of this research is to find out how the museum's interior can meet the purpose in the aspect of education to recreation, especially in cultural museums with the experience of the space formed.

\section{Methods}

This research uses qualitative methods, with data collection carried out with three stages (triangulation), including interviews, observations, and documents (Raco, 2010). The first step is to capture phenomena related to museums, analyze the suitability of museum objectives and applications in museum interiors, the potential of museums in East Java, and then examine interior design elements that can support museum purposes, especially in cultural aspects of museums. In support of this research, the interview stage was conducted with one of the educators from the Ganesya Museum, Malang, on November 8, 2020. Ganesya Museum is a cultural museum that has a cultural collection (history and wayang). This interview is semi-structured, with the main topic being museum collection objects. The interview results in inventory and arrangement of displays of collectables in several types of cultures in East Java.

Furthermore, the observation stage is carried out at the Ganesya Museum to observe aspects of the museum's interior that support museum goals in terms of education, recreation, and conservation. The observation was made on the same day as the interview. As a reference, the variable experience of this space is based (Sari, 2005), that the experience of space is influenced by several variables such as points, lines, shapes, colours, light, ergonomics, and the atmosphere of the space. At this stage, researchers position themselves as participants to experience for themselves and analyze the variables of spatial experience and other elements that impact the museum's goals. This observation found that there are several elements of the museum's interior with the type of culture that impact the spatial experience that affects the educational and recreational process of visitors. Such as the design and ergonomics of collection displays that have designs supporting collection objects and room atmosphere, lighting applications and culturally appropriate interior atmosphere, and the flow of visitors in viewing collection objects. The collected data results are elaborated so that it is found that the spatial experience is vital in fulfilling the purpose of the museum in terms of education, recreation, and conservation, especially in the interior of cultural museums. These results will be visualized in the museum's interior design with a design concept, with a case study of the East Java Cultural Museum. 


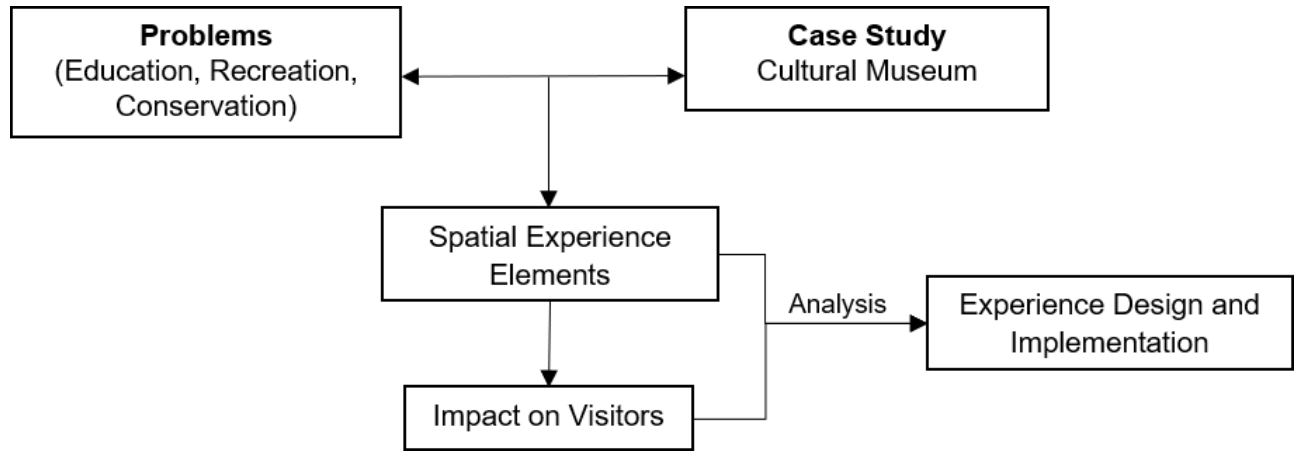

Figure 2.1. Research Framework (Author, 2021)

\section{Result and Discussion}

\subsection{Result}

A museum as an institution that serves the community has a purpose in education, recreation, and conservation. The interior of the museum must be able to provide information and be well received by the public. The purpose of the museum in terms of recreation means that the museum's interior must be fun and support the educational process according to the type of museum. In addition, keeping collectables safe and accessible in the maintenance process is also one of the museum's goals in terms of conservation. To achieve these goals, the museum must have a design that provides a spatial experience. A table of analysis was made to explain the impact of the application of spatial experience elements to the purpose of the museum with a cultural museum case study. This table contains literature related to interior elements taken from the collection of data, the impact on collectables and visitors in achieving the museum's purpose, and the results of the analysis obtained.

Table 3.1. Cultural Museum Spatial Experience Analysis (Author, 2021)

\begin{tabular}{|c|c|c|c|}
\hline $\begin{array}{c}\text { Spatial } \\
\text { Experience } \\
\text { Elements }\end{array}$ & General Literature & Impacts & Result Analysis \\
\hline $\begin{array}{l}\text { Display Case } \\
\text { (shape and } \\
\text { ergonomics) }\end{array}$ & $\begin{array}{l}\text { - The displayed shape is } \\
\text { designed based on the } \\
\text { needs of collectables, } \\
\text { visitors, and the } \\
\text { atmosphere of the space } \\
\text { to be achieved (Dahlan \& } \\
\text { Sarihati, 2019). } \\
\text { - Ornamental elements in } \\
\text { traditional East Java } \\
\text { become an essential part } \\
\text { of the interior } \\
\text { arrangement, including the } \\
\text { ornamentation of } \\
\text { geometric motifs, flora, and } \\
\text { fauna (Budiwiyanto, 2010). }\end{array}$ & $\begin{array}{l}\text { - The shape and size of } \\
\text { diverse collection objects } \\
\text { (interviews and literature) } \\
\text { can attract visitors, but the } \\
\text { poor ergonomics of } \\
\text { collection displays make it } \\
\text { difficult for visitors to reach } \\
\text { the collection objects. } \\
\text { - The rigid shape has a rigid } \\
\text { and firm character that can } \\
\text { make visitors focus, but } \\
\text { the atmosphere caused } \\
\text { becomes stiff. } \\
\text { - The organic form has a fun } \\
\text { and refreshing character } \\
\text { for visitors, but overuse of } \\
\text { the organic form can make } \\
\text { visitors not focus on } \\
\text { collectables and } \\
\text { information in the } \\
\text { exhibition area. }\end{array}$ & $\begin{array}{l}\text { The application of rigid shapes } \\
\text { will dominate the display of } \\
\text { cultural museum collections } \\
\text { because the shape is practical } \\
\text { if applied to space (adjusting } \\
\text { the collection objects } \\
\text { interviews and literature). In } \\
\text { addition, the application of } \\
\text { organic forms will be applied to } \\
\text { support the recreational aspect } \\
\text { of the museum so that the } \\
\text { combination of these forms will } \\
\text { be able to make visitors } \\
\text { focused but still fun } \\
\text { (conservation, education, and } \\
\text { recreation). This combination } \\
\text { of shapes can be a geometric } \\
\text { motif found in the traditiona } \\
\text { features of East Java. }\end{array}$ \\
\hline $\begin{array}{l}\text { Room } \\
\text { Athmosphere }\end{array}$ & $\begin{array}{l}\text { - The atmosphere in the } \\
\text { showroom can be adjusted }\end{array}$ & $\begin{array}{l}\text { The interior atmosphere can } \\
\text { support cultural collection }\end{array}$ & $\begin{array}{l}\text { An atmosphere that adjusts } \\
\text { collection objects and types of }\end{array}$ \\
\hline
\end{tabular}




\begin{tabular}{|c|c|c|c|}
\hline $\begin{array}{c}\text { Spatial } \\
\text { Experience } \\
\text { Elements }\end{array}$ & General Literature & Impacts & Result Analysis \\
\hline $\begin{array}{l}\text { (themes, } \\
\text { concepts, } \\
\text { style, and } \\
\text { colors) }\end{array}$ & $\begin{array}{l}\text { to the exhibits displayed to } \\
\text { liven up the atmosphere } \\
\text { (recreation) and support } \\
\text { collection objects } \\
\text { (education) (Wulandari, } \\
\text { 2014). } \\
\text { - Colour is the shaper of the } \\
\text { atmosphere of space that } \\
\text { is easily captured by the } \\
\text { human sense of vision to } \\
\text { impact human psychology } \\
\text { (Putri, Handajani, \& } \\
\text { Amiuza, 2013). } \\
\text { - The interior of a traditional } \\
\text { East Java house has a } \\
\text { formal, quiet, simple, open } \\
\text { yet authoritative } \\
\text { atmosphere (Budiwiyanto, } \\
\text { 2010). }\end{array}$ & $\begin{array}{l}\text { objects so that visitors better } \\
\text { understand the information } \\
\text { provided in the museum. } \\
\text { The atmosphere that suits } \\
\text { the type of museum or } \\
\text { collection objects can make } \\
\text { visitors more interested in } \\
\text { exploring the exhibition area } \\
\text { so that a spatial experience } \\
\text { arises because the design } \\
\text { appears as an embodiment } \\
\text { of cultural values (Santosa, } \\
2005 \text { ). } \\
\text { The presence of colours } \\
\text { relevant to cultural museums } \\
\text { (case studies) and } \\
\text { collectables will create an } \\
\text { atmosphere that supports } \\
\text { visitors' educational and } \\
\text { recreational processes. }\end{array}$ & $\begin{array}{l}\text { museums can be applied to } \\
\text { support the museum's purpose } \\
\text { in the aspect of education and } \\
\text { recreation. In the case of } \\
\text { studies, the traditional and } \\
\text { contemporary crawling of East } \\
\text { Java can be a solution to the } \\
\text { museum atmosphere because } \\
\text { this style can support the } \\
\text { museum's purpose. }\end{array}$ \\
\hline Lighting & $\begin{array}{l}\text { According to (Wulandari, } \\
\text { 2014) lighting should make it } \\
\text { easier for visitors to access } \\
\text { and view the information in } \\
\text { the showroom area. The } \\
\text { lighting must adjust the } \\
\text { conservation and } \\
\text { atmospheric needs to be } \\
\text { displayed. }\end{array}$ & $\begin{array}{l}\text { Lighting techniques focused } \\
\text { on cultural collection objects } \\
\text { and existing information } \\
\text { make visitors focused and } \\
\text { interested in seeing them. } \\
\text { This lighting technique can } \\
\text { also build the atmosphere of } \\
\text { the space so that it has an } \\
\text { impact on the visitor's spatial } \\
\text { experience. }\end{array}$ & $\begin{array}{l}\text { Lighting techniques focused } \\
\text { on cultural collection objects } \\
\text { and existing information make } \\
\text { visitors focused and interested } \\
\text { in seeing them. This lighting } \\
\text { technique can also build the } \\
\text { atmosphere of the space so } \\
\text { that it has an impact on the } \\
\text { visitor's spatial experience. }\end{array}$ \\
\hline Storyline & $\begin{array}{l}\text { - The storyline can be a } \\
\text { medium of communication } \\
\text { between the museum and } \\
\text { visitors. The existence of a } \\
\text { storyline at the museum } \\
\text { can help visitors get } \\
\text { information and be } \\
\text { interested in seeing other } \\
\text { information } \\
\text { (Moortheeswari, 2015). } \\
\text { - According to (Parwoto, } \\
\text { Peja, \& Setiawan), there } \\
\text { are three approaches to } \\
\text { the museum storyline: } \\
\text { chronology, taxonomic, } \\
\text { and thematic. }\end{array}$ & $\begin{array}{l}\text { Objects of diverse cultural } \\
\text { museum collections } \\
\text { (interview and observation } \\
\text { data) can make visitors } \\
\text { unable to receive information } \\
\text { well if the grouping of } \\
\text { collection objects is not } \\
\text { good. } \\
\text { There are three storyline } \\
\text { presentation techniques, one } \\
\text { of which is divided into types } \\
\text { of collectables (taxonomic). } \\
\text { This technique can make } \\
\text { visitors better understand } \\
\text { and recognize the collection } \\
\text { objects that are quite a lot in } \\
\text { the museum. }\end{array}$ & $\begin{array}{l}\text { Based on the analysis, the } \\
\text { storyline is part of the } \\
\text { presentation technique in the } \\
\text { museum. Storylines by } \\
\text { dividing over similar collection } \\
\text { objects can be applied. The } \\
\text { existence of a storyline with a } \\
\text { combination of space } \\
\text { atmosphere will make visitors } \\
\text { feel a spatial experience. }\end{array}$ \\
\hline $\begin{array}{l}\text { Interactive } \\
\text { Aspects }\end{array}$ & $\begin{array}{l}\text { Interactive techniques will } \\
\text { offer a memorable spatial } \\
\text { experience for visitors. This } \\
\text { technique also makes it } \\
\text { easier for visitors to get } \\
\text { information more clearly. } \\
\text { This aspect needs to grab } \\
\text { visitors' attention by creating } \\
\text { contextual interactive, easy } \\
\text { to navigate, and attractive } \\
\text { designs (Salim, R, \& } \\
\text { Rachmayanti, 2018). }\end{array}$ & $\begin{array}{l}\text { With interactive facilities, } \\
\text { visitors can also actively be } \\
\text { in the museum. Visitors can } \\
\text { interact in the exhibition area } \\
\text { to give rise to a spatial } \\
\text { experience in getting } \\
\text { information in the museum. }\end{array}$ & $\begin{array}{l}\text { The existence of interactive } \\
\text { aspects in the exhibition area } \\
\text { can be applied to create a } \\
\text { spatial experience from which } \\
\text { this can meet the purpose of } \\
\text { the museum in the aspect of } \\
\text { education and recreation. The } \\
\text { existence of this aspect can } \\
\text { make visitors learn and seek } \\
\text { information in a more } \\
\text { enjoyable way. }\end{array}$ \\
\hline
\end{tabular}


In (Sari, 2005), there are several variables that affect the spatial experience, such as dots, lines, shapes, colours, light, ergonomics, and the atmosphere of the space. These variables are processed (selected and centred) with the data collection results, then bring up five elements of spatial experience on the analysis table and the analysis results obtained (Table 3.1). These five elements are explained more focused by the design visualization that is united in an Experience Design.

\subsection{Discussion}

After going through the stages of data collection and analysis, a design solution appears namely Experience Design. Experience Design will be a design that supports the achievement of the museum's goals in education, recreation, and conservation. Experience Design describes the elements that impact the visitor spatial experience with a case study of the East Java Cultural Museum.

\section{- Storyline}

One of the things to do before designing the museum's interior is to determine the storyline to support the information conveyed to visitors. Building a storyline can be a strategy to highlight the characteristics of collectables (Falco \& Vassos, 2017) to create a visitor spatial experience. Cultural museums have various collection objects that some of the collection objects are not known when the emergence of this culture because culture is a human identity, so it will continue to be interconnected with humans in life (Kistanto, 2015). In the case study of cultural museums, grouping storylines focusing on similar collection objects can make it easier for visitors to receive information and conservation for collectables (Table 3.1). The grouping of similar collection objects will help to detail the sub-themes of the cultural museum storyline to better support the educational and recreation process of the exhibition area. It will also help describe the theme, concept, and style of the interior design of the cultural museum.

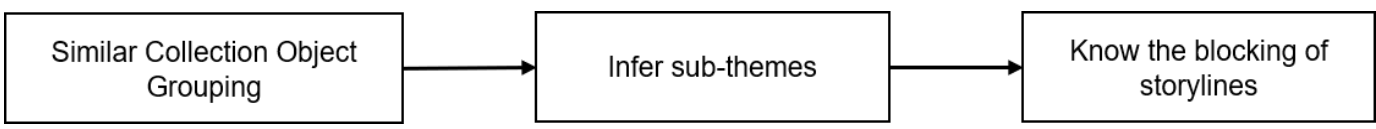

Figure 3.1. Cultural Museum Storyline Framework (Author, 2021)
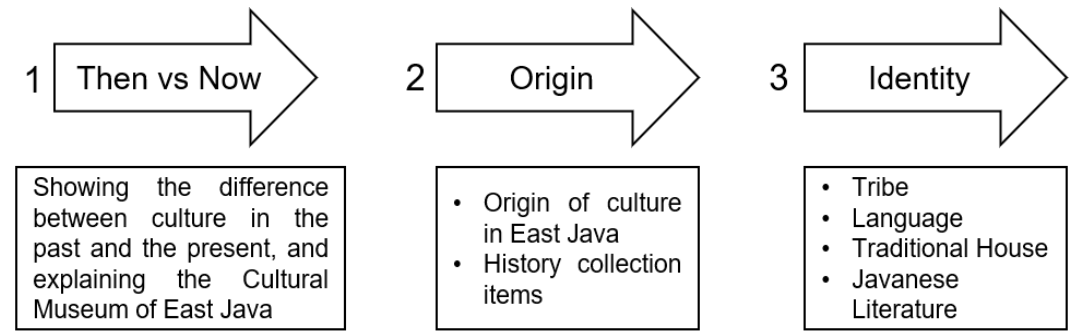

4

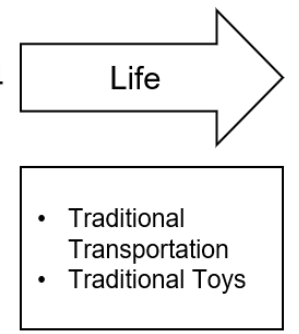

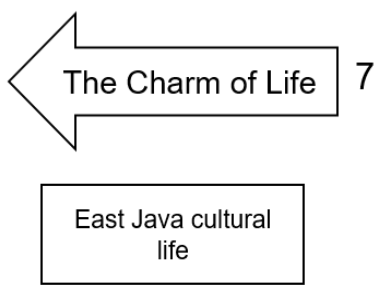
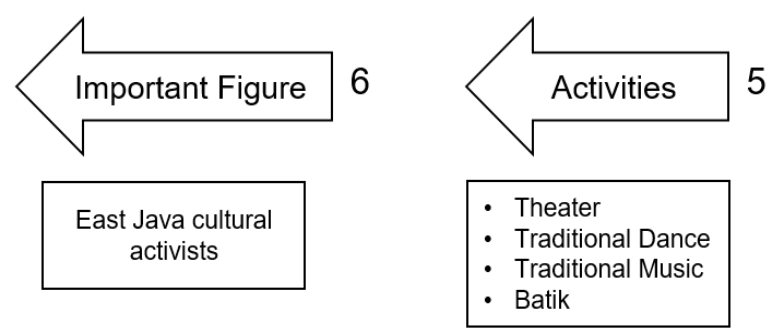

Figure 3.2. Storyline Implementation (Author, 2021) 
In (Figure 3.2) is a storyline implementation of the East Java Cultural Museum. This storyline is divided into seven cultural spaces that are divided into sub-spaces with similar collection objects. This storyline concept has a plot that starts by showing the difference between past and present cultural life as an introduction, then entering the history section, then introducing an essential thing the cultural identity of East Java, which includes tribes, languages, and traditional houses, and literature. After visitors know the basics, continued by showing how cultural life (life gallery), then showing cultural activities (activities gallery), visitors are invited to recognize cultural activists after knowing about the culture. Lastly, visitors can see that culture has a significant role in life by showing the past to present cultural process.

\section{- Room Atmosphere}

The determination of the storyline also impacts the theme, concept, and style that will be implemented. The design itself emerges as an embodiment of cultural values (Santosa, 2005). After knowing the storyline formed, the atmosphere that adjusts the collection objects (sub-theme storyline) and the type of museum can be a solution in the cultural museum. Following case studies, applying traditional Javanese style can be a solution because it supports bringing up the atmosphere of space by existing collection objects to support the delivery of information and recreation to the flatter. In addition, the colour characteristics of the traditional Javanese style are brown, which gives a serious-focused and comfortable impression. The application of neutral colours such as black and white can also support balancing the atmosphere in the museum because black gives a solid and safe impression while in the museum. White colour will give the impression of clean, soothing, and refreshing. White and black colours can be obtained by bringing out contemporary styles that have the character of using natural materials that are in accordance with traditional styles, giving a simple impression so that visitors can focus more on the collection of objects and information in the museum. The incorporation of traditional and contemporary styles into a solution to create a spatial experience wrapped in Experience Design to support museum goals.

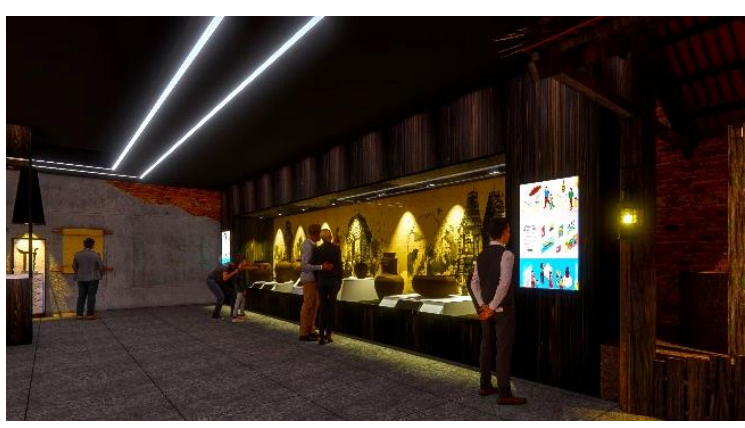

Figure 3.3. Historical Area (Author, 2021)

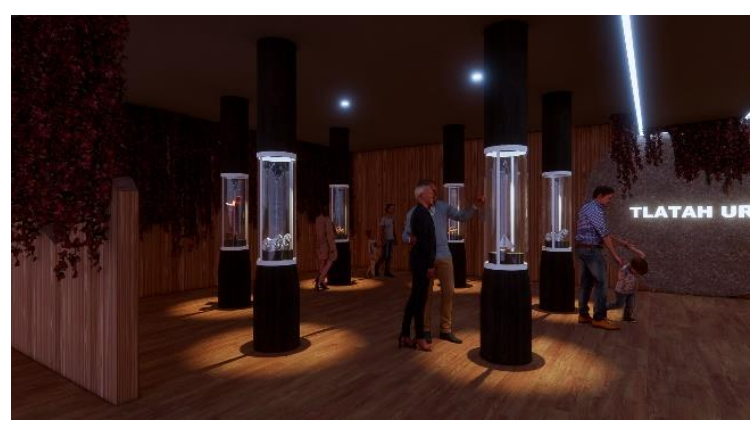

Figure 3.4. Traditional Toys Area (Author, 2021)

As an implementation, the theme taken in this case study is "Cultural Charm of East Java". The existence of this theme will show the charm of each type of culture in East Java (storyline) so that visitors better recognize East Java culture (educational purposes). The concept is the "Teleportation of Cultural Space". This concept will invite visitors to teleport into several cultural spaces/galleries (according to the storyline), which will support the visitor spatial experience (recreational purpose). In (Figure 3.3 \& Figure 3.4) is a visualization of experience design in contemporary, traditional style applications with themes and concepts that have been described. 


\section{- Museum Display Case}

Display collection objects should pay attention to collection objects. The shape of the display can be based on the needs of visitors and the atmosphere of the space to be achieved; the atmosphere of the space itself forms the spatial experience (Dahlan \& Sarihati, 2019). The rigid shape is applied because it has an effective shape in its placement and maintenance (conservation). The combination of rigid and organic shapes can make visitors focus while in the museum but still feels fun (Table 3.1). In the cultural museum, this combination will be raised by the transformation of form. Examples can collaborate inspiration from the basic form of traditional culture that corresponds to the type of museum and collection objects. This transformation of form is a form of embodiment of cultural value in the interior design of cultural museums. Shape transformation creates a character in the space that can support the atmosphere of the space so that visitors can feel the experience of the space. Shape transformation can be applied to decorative elements of the display.

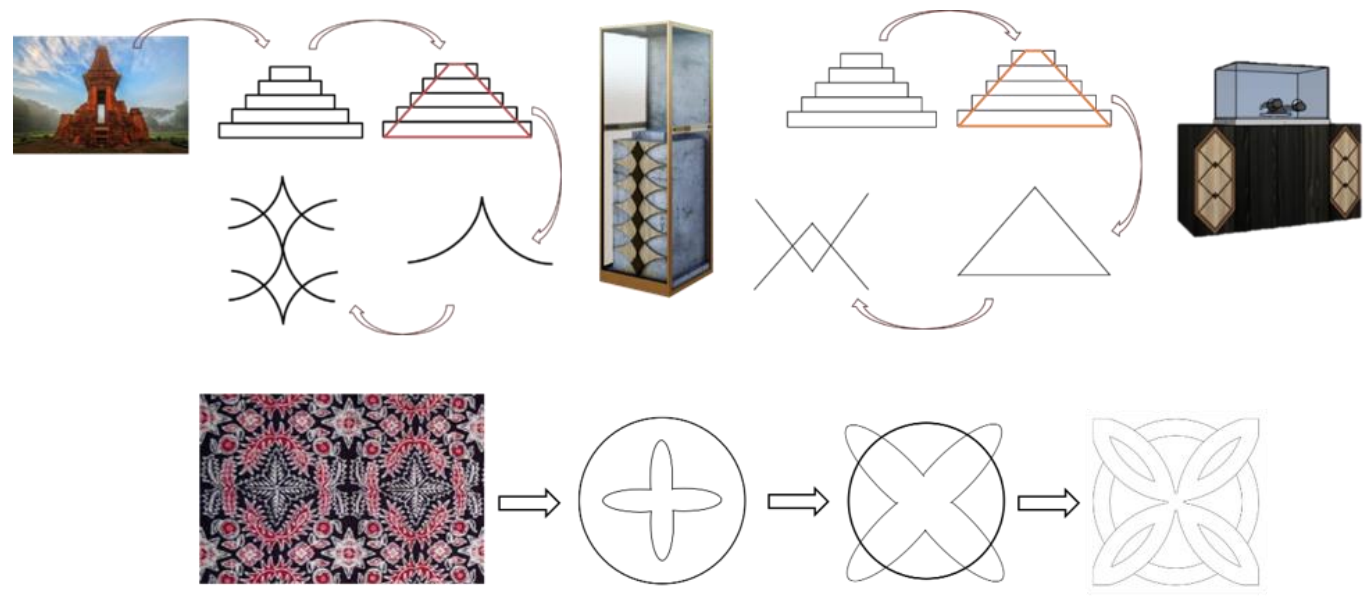

Figure 3.5. Shape Transformation (Author, 2021)

In (Figure 3.5) is a visualization of the concept of form from the analogy of Bajang Ratu Temple to display the keris collection. Bajang Ratu Temple is one of the cultural and historical relics of East Java. This temple was used as the main door to the Majapahit kingdom. This decoration provided cultural value in the origin sub-theme as the first entrance to explore the museum's collection objects. (Figure 3.5) is a transformation of Mojokerto batik that is applied as a decorative element of the museum's backdrop lobby, has optimistic, happy, and unity cultural value that aims to make the cultural museum can be a key to the unity of society in culture by providing cultural museum interiors that support the purpose of the museum in terms of education, recreation, and conservation.

\section{- Museum Lighting}

Lighting in museums should pay attention to lighting standards, especially for collectables. In addition, lighting must support the information to be conveyed. Visitor activity is related to the spatial experience that appears in the interior of the museum. The application of dramatic lighting can be a solution to the visitor spatial experience while keeping in mind the museum's lighting standards. Dramatic lighting is lighting that makes visitors focus on collectables and form the atmosphere of the museum space. This dramatic lighting is applied with high and low-intensity lighting (bright and dim) and strategically laying of light points in the exhibition area. This difference in lighting intensity can still make visitors comfortable to be able to explore the museum. Lighting that focuses on illuminating collection objects uses 
individual dimming lighting effects (lighting that directly illuminates collection objects one by one/not group).

The intensity of lighting on the collection objects will follow the standardization of the museum, namely fabrics, paintings, photographs, and puppets with an intensity of 50 lux, for wood and plastic with an intent of 100 lux. Metals and ceramics will use intensity of 300 lux. This lighting concept is listed in the Experience Design that is the solution of the museum spatial experience. This lighting visualization can be seen in (Figure 3.6 \& Figure 3.7) which places the lighting as an accent and general with colours that are not blinding to the eye. Cultural museums have various materials from collection objects, so the colours used as lighting in the East Java Cultural Museum are cool white and warm white. Warm white colour has the advantage of not inducing heat and UV light, so this colour protects collection objects from the onset of damage.

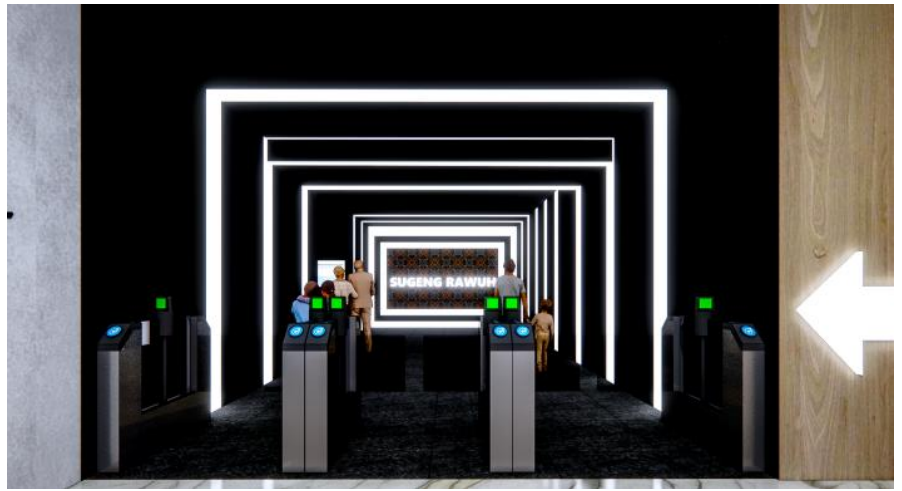

Figure 3.6. Exhibition Entrance-Dramatic Lighting Visualization (Author, 2021)
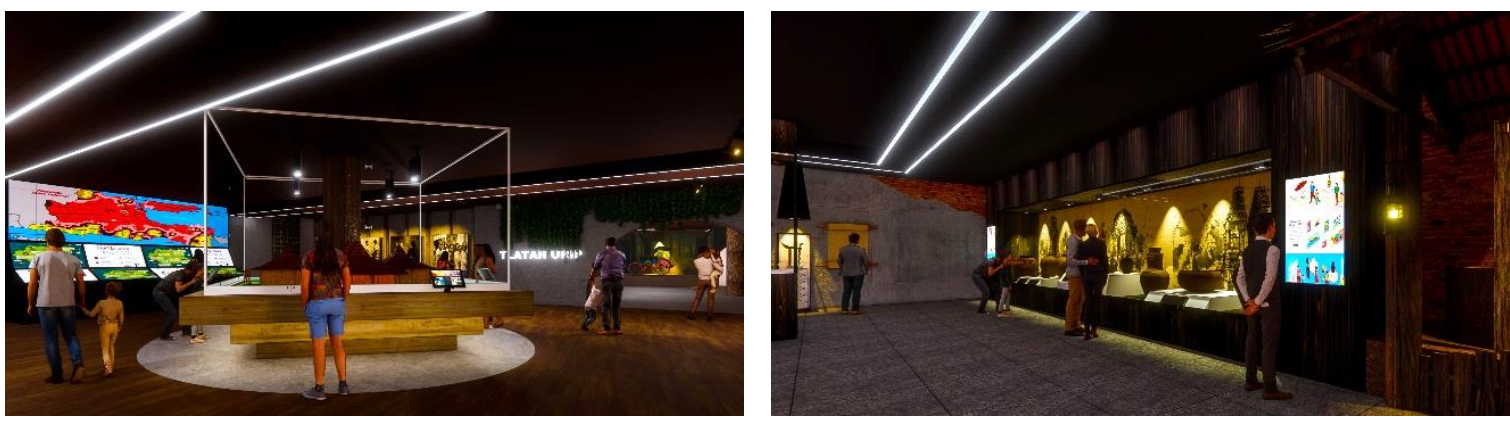

Figure 3.7. Dramatic Lighting Visualization (Author, 2021)

\section{- Interactive Aspects}

So that visitors can be active while in the museum, interactive aspects become one of the solutions that can be done (Table 3.1). One example of interactive media is the application of technology. Technology can open up innovative opportunities in conveying information and providing education that produces spatial experiences (Falco \& Vassos, 2017). Its implementation at the East Java Cultural Museum, in addition to using technology such as touchscreen displays applied. Visitors can be active with interactive media that are in accordance with the storyline in the museum. This media makes a spatial experience to visitors that has an impact on the education provided to visitors. This medium is also one way of getting information in a more enjoyable way (recreational purpose). For example, visitors can feel how to make jars in the exhibition area of history (Figure 3.9). Visitors can find out the writing, intonation, and accent of East Java with interactive media (Figure 3.10). 
Interactive displays also are applied to introduce East Java cultural activities with video mapping (Figure 3.11). Next, "open it" can introduce cultural activist figures by opening photos of cultural activist figures (Figure 3.12). An example given is a solution to create spatial experiences that are summarized in "Experience Design".

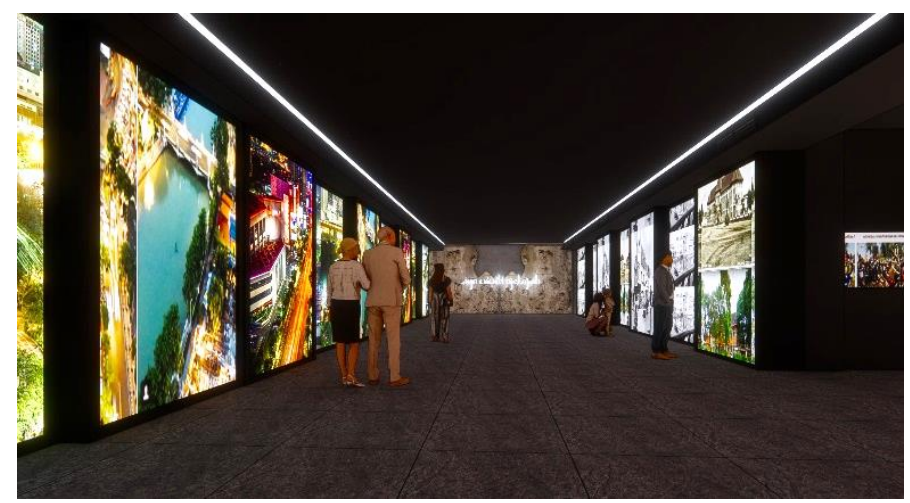

Figure 3.8. Technology Display (Author, 2021)

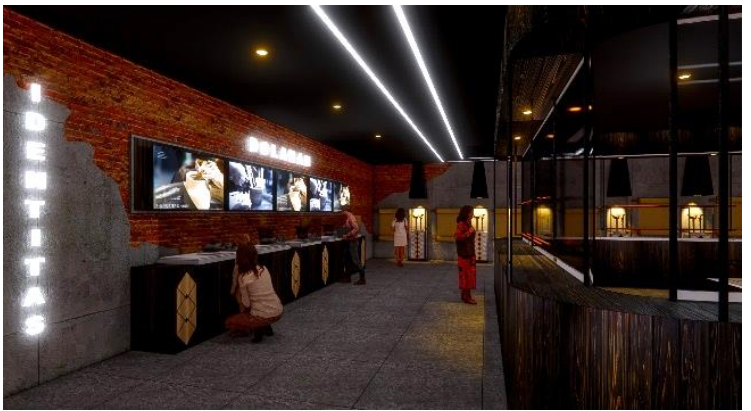

Figure 3.9. Interactive-Making Jars (Author, 2021)

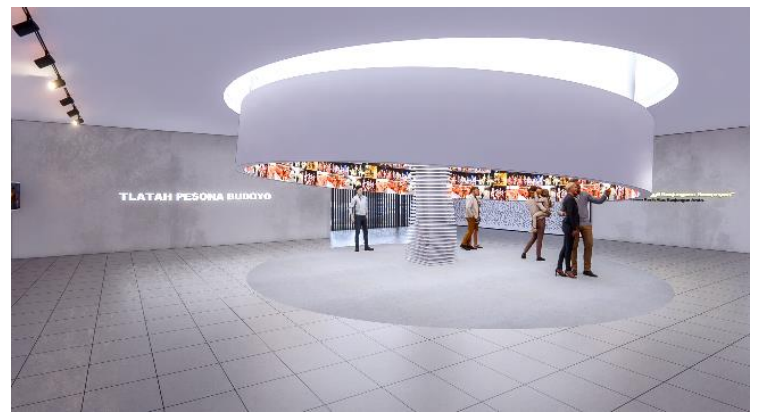

Figure 3.11. Interactive-Video Mapping (Author, 2021)

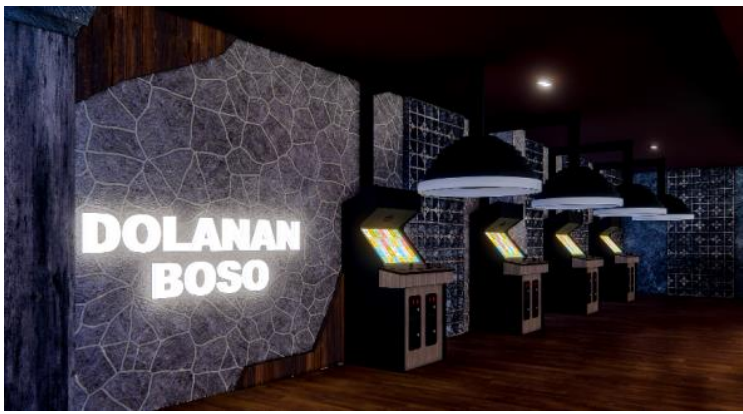

Figure 3.10. Interactive-Javanese Language (Author, 2021)

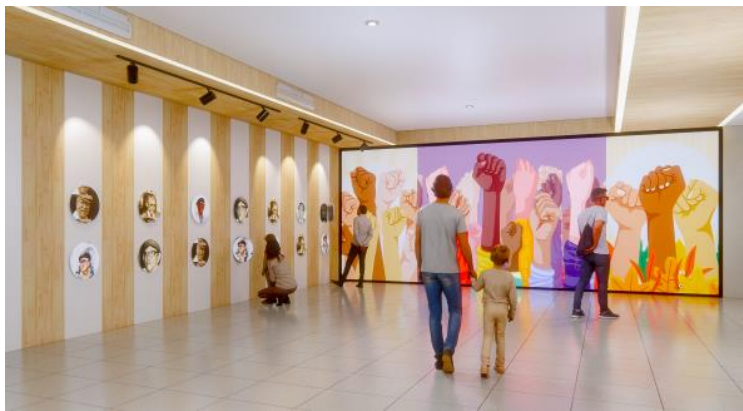

Figure 3.12. Interactive-Open It (Author, 2021)

\section{Conclusion}

Based on the results and discussions that have been conducted, it can be concluded that the museum's interior becomes a vital role in achieving the museum's purpose. One solution is to bring up a spatial experience for visitors. Five important aspects influence the spatial experience of visitors in the museum, focusing on cultural museums. These five aspects are solved by Experience Design. Experience Design includes applying themes, concepts, and 
styling (room atmosphere) that suits the type of collection and museum objects by collaborating with traditional and contemporary style. The application of storylines that focus on grouping similar collection objects can be a solution to provide education that has an impact on the visitor spatial experience. In addition, lighting techniques that create dramatic lighting also need to be considered. Collection displays with shape transformation can be a solution to represent collection objects and support the atmosphere of the room that will impact the purpose of the museum in aspects of education, recreation, and conservation. The last is the provision of interactive media that does not only come from technology. The existence of interactive displays can make visitors actively participate in the exhibition area, thus making visitors get information in a fun way. These five aspects collaborate into "Experience Design".

In other cultural museums, "Experience Design" can be applied with the same spatial experience elements. What distinguishes is that the elements of this spatial experience will collaborate with certain storylines and traditional cultures so that the interior design results of other cultural museums will remain by the type of culture. Most importantly, the design will remain by the museum's purpose in aspects of education, recreation, and conservation. In this study, it can be seen that the role of the spatial experience element influences the museum that displays cultural collections. So the recommendation for other types of museums is to consider analyzing the museum's interior elements that impact the spatial experience in fulfilling the purpose of the museum. "Experience Design" can be used as a reference to achieve the right solution.

\section{References}

Banaim, H. S., \& Sarihati, T. (2019). Pengaruh Atmosfir Ruang Terhadap Perancangan Museum Sejarah Kehidupan. Jurnal Atrat, 160-168.

Budiwiyanto, J. (2010). Makna Penataan Interior Rumah Tradisional Jawa. Pendhapa, 1(1).

Dahlan, M. H., \& Sarihati, T. (2019). Perancangan Museum Motor Indonesia Dengan Pendekatan Experience. ATRAT: Jurnal Seni Rupa, 7(2), 150-159.

Dal Falco, F., \& Vassos, S. (2017). Museum Experience Design: A Modern Storytelling Methodology. The Design Journal, 20(sup1), S3975-S3983.

Elgammal, I., Ferretti, M., Risitano, M., \& Sorrentino, A. (2020). Does Digital Technology Improve The Visitor Experience? A Comparative Study in The Museum Context. Int. J. Tourism Policy, 47-67.

Falk, J. H. (2016). Identity and The Museum Visitor Experience. Routledge.

Gunawan, J. A., de Yong, S., \& Rakhmawati, A. (2020). Kajian Sensory/Panca Indra pada Interior Bangunan Heritage Kafe di Surabaya. Jurnal Desain Interior, 5(1), 11-22.

Kistanto, N. H. (2015). Tentang Konsep Kebudayaan. Sabda: Jurnal Kajian Kebudayaan, 10(2).

Lelo, L., \& Laksono, M. A. Perancangan Desain Interior Museum Seni Rupa dan Keramik Jakarta. Narada, 5(1), 11-24.

Moortheeswari, S. (2015). Telling Stories With Museum Objects - Reflection on Interpretation. ICOM SIDOC, 1-8.

Mufidah, I. (2019). Potret Museum Di Indonesia. Kementerian Pendidikan dan Kebudayaan Sekretariat Jenderal Pusat Data dan Statistik Pendidikan dan Kebudayaan.

Nahak, H. M. (2019). Upaya Melestarikan Budaya Indonesia di Era Globalisasi. Jurnal Sosiologi Nusantara, 5(01).

Parwoto, B. D., Peja, E., \& Setiawan, F. (2020). Penataan Benda Koleksi Museum Terhadap Kepuasan Pengunjung di Museum Wayang dan Museum Sejarah Jakarta Kawasan Kota Tua Jakarta. IKRA-ITH HUMANIORA: Jurnal Sosial Dan Humaniora, 4(2), 3549. 
Putri, S. S., Handajani, R., \& Amiuza, C. (2013). Penerapan Unsur Warna pada Interior Museum. Arsitektur UB.

Raco, J. R. (2010). Metode Penelitian Kualitatif Jenis. Karakteristik, dan Keunggulannya, Grasindo, Penerbit PT Gramedia Widiasarana Indonesia, Jakarta.

Salim, P., Christianto, R., \& Rachmayanti, S. (2018). Perancangan Desain Interior Museum Dengan Teknik Interaktif Sebagai Ruang Publik Masa Kini. Jurnal Dimensi Seni Rupa dan Desain, 15(1), 45-54.

Santosa, A. (2005). Pendekatan Konseptual dalam Proses Perancangan Interior. Dimensi Interior, 3(2).

Sari, S. M. (2005). Implementasi Pengalaman Ruang Dalam Desain Interior. Dimensi Interior, 165-176.

Suyono, B. H., Sarihati, T., \& Wulandari, R. (2019). Suasana Ruang Sebagai Solusi Perancangan Museum Marmer Indonesia. ATRAT: Jurnal Seni Rupa, 7(2), 139-149.

Wulandari, A. A. A. (2014). Dasar-Dasar Perencanaan Interior Museum. Humaniora, 5(1), 246-257. 